See discussions, stats, and author profiles for this publication at: https://www.researchgate.net/publication/327868994

\title{
Moral Disengagement in Middle School Students: Survey in Religious Education
}

Article in International Journal of Engineering and Technology · September 2018

CITATIONS

0

4 authors, including:

Reza Rachmadtullah

PGRI University of Adi Buana

26 PUBLICATIONS 29 CITATIONS

SEE PROFILE
READS

24 


$\xi=-1$

\title{
Moral Disengagement in Middle School Students: Survey in Religious Education
}

\author{
Yufiarti $^{1 *}$, Sri Nuraini ${ }^{2}$, Muhammad Solihin $^{3}$, Reza Rachmadtullah $^{4}$ \\ ${ }^{1,2,4}$ Universitas Negeri Jakarta. Indonesia \\ ${ }^{3}$ Universitas Islam Negeri Jambi. Indonesia \\ *Corresponding authorE-mail: yufiarti@unj.ac.id
}

\begin{abstract}
Indonesian culture has many schools which based on religion. The main objective of the Islamic school is to make their students have moral or wonderful behavior. The purpose of this study was to investigate moral disengagement of students at religious education. This survey on 171 students included female and male. Data analysis used descriptive as graph and percentage. Children can enroll to the religious schools. Profile shows that many children varieties such as gender, age. Student's at moral disengagement was multiple diverse.
\end{abstract}

Keywords: moral disengagement, religious education

\section{Introduction}

Indonesia has much religious education which basis in Islamic religion because Islam is the majority religion. In Islamic education, Islamic values can be inspirational and becoming the spirit of education. Moreover, moral education practiced in these schools relies on Islamic values. So that religious education and religious values have the power to inspire and teach children about morals (1). Rossano (2008) identifies moral experts/exemplars and see if religious people dominated their ranks, the most commonly cited moral paragons are often religious such as Gandhi, Mather Teresa, and so on. And he also reviews the current literature on religion and moral behavior there are link between religion and moral behavior (2). Muslims believe that moral behavior presupposes faith and that faith is genuine only if it results in moral behavior (3).

Religious education has a very significant influence in shaping morals (4) . Menurut Roberts \& Yamane, 2011 (5) said that in general the individual adherents of religion regard religion very closely related to the teachings of daily morality. Morality in religion is also seen as a noble, order in social life that is used as a guide. In a way, religion gave birth to morals. So a person who is religious and practice his religious teachings well should also have good morals(6,7)

Moral teachings contained in a religion include two kinds of rules. On the one hand, there are sometimes somewhat detailed rules about unclean food, fasting, worship, and so on. Such rules are often different from different religions. On the other hand, there are more general ethical rules that go beyond certain religious interests, such as: do not kill, do not lie, do not commit adultery, do not steal (4).

Many research studies about the relation between religious education to the moral but rarely to moral disengagement. Furthermore this researched investigated of moral disengagement of students at religious education. Bandura's theoretical framework explained social cognitive theory of morality. He states that people can eliminate anticipation of such reaction through of psychosocial mechanisms collectively termed Moral Disengagement (MD), such as reconstructing amoral behavior, obscuring personal responsibility, misrepresenting injurious consequences and blaming the victims $(8-10)$

\section{Method}

This research is done on Islamic Junior High School Bekasi. Respondent includes 171 students. Data analysis used descriptive as graph and percentage. Collecting data use instruments of Moral disengagement such below:

Table 1: Instruments of Moral Disengagement

\begin{tabular}{|c|c|c|c|c|}
\hline \multirow{2}{*}{ Dimension } & \multirow{2}{*}{ Indicator } & \multicolumn{2}{|c|}{ Object } & \multirow[t]{2}{*}{ Total } \\
\hline & & Favorable & Unfavorable & \\
\hline & \multirow{2}{*}{$\begin{array}{c}\text { Moral Justifica- } \\
\text { tion }\end{array}$} & \multirow{2}{*}{$1,2,8$} & \multirow{2}{*}{15} & \multirow{2}{*}{4} \\
\hline Reconstructing & & & & \\
\hline Immoral & \multirow{2}{*}{$\begin{array}{l}\text { Euphemistic } \\
\text { Labeling }\end{array}$} & \multirow{2}{*}{5,9} & \multirow{2}{*}{ - } & \multirow{2}{*}{2} \\
\hline Behavior & & & & \\
\hline & \multirow{2}{*}{$\begin{array}{c}\text { Advantageous } \\
\text { Comparison }\end{array}$} & $10,16,23$ & \multirow{2}{*}{ - } & \multirow{2}{*}{4} \\
\hline & & & & \\
\hline Obscuring & \multirow{2}{*}{$\begin{array}{c}\text { Displacement of } \\
\text { Responsibility }\end{array}$} & \multirow{2}{*}{$4,12,19$} & \multirow{2}{*}{3} & \multirow{2}{*}{4} \\
\hline Personal & & & & \\
\hline Responsibility & \multirow{2}{*}{$\begin{array}{c}\text { Diffusion of } \\
\text { Responsibility }\end{array}$} & \multirow{2}{*}{$\begin{array}{c}17,24,25, \\
26\end{array}$} & \multirow[b]{2}{*}{ - } & \multirow[b]{2}{*}{4} \\
\hline & & & & \\
\hline \multicolumn{5}{|l|}{ Misrepresenting } \\
\hline Injurious & \multirow{2}{*}{$\begin{array}{c}\text { Distortion of } \\
\text { Consequences }\end{array}$} & \multirow{2}{*}{$7,13,18$} & \multirow{2}{*}{-} & \multirow{2}{*}{3} \\
\hline Consequences & & & & \\
\hline Blaming the & Dehumanization & $14,11,20$ & 21 & 4 \\
\hline Victims & \multirow{2}{*}{$\begin{array}{c}\text { Attribution of } \\
\text { Blame }\end{array}$} & \multirow{2}{*}{6,22} & \multirow[b]{2}{*}{ - } & \multirow{2}{*}{2} \\
\hline & & & & \\
\hline \multicolumn{2}{|c|}{ Total } & \multicolumn{2}{|r|}{26} & 26 \\
\hline
\end{tabular}




\section{Results and Findings}

\subsection{Students Profile}

This following constitute observational respondent picture bases gender that is divided becomes male and female. That respondent picture can be seen deep this following table.

Table 2: Total Respondent bases Gender

\begin{tabular}{|c|c|c|}
\hline \multicolumn{3}{|c|}{ Table 2: Total Respondent bases Gender } \\
\hline Female & Frequency & Percentage \\
\hline Male & 75 & $43.9 \%$ \\
\hline Total & 96 & $56.1 \%$ \\
\hline
\end{tabular}

Table upon acknowledged that male respondent amount more a lot of than respondent female. Total female respondent 75 school girls (43. 9\%), meanwhile total male respondent 96 students (56. 1\%). It can be concluded that male is more than female. This school enrolled students based on gender.

\subsection{Class}

Furthermore students profile bases on class..This following constitute observational respondent picture bases class. Subdivided respondent becomes three group which is classes 7, 8, and 9 .

Table3: Class Profile

\begin{tabular}{|c|c|c|}
\hline Age & Frequency & Percentage \\
\hline Grade 7 & 50 & $29.2 \%$ \\
\hline Grade 8 & 72 & $42.1 \%$ \\
\hline Grade 9 & 49 & $28.7 \%$ \\
\hline Total & 171 & $100 \%$ \\
\hline
\end{tabular}

Table upon acknowledged that respondent at most from class 8 , followed by class 7, and class last 9 . Respondent class 7 a number 50 students $(29.2 \%)$, meanwhile 8 number of 72 students $(42.1 \%)$, and 9 a number 49 students (28. 7\%). Total number 146 students,

\subsection{Age}

This following constitute respondent picture bases age. Spread respondent in range age 12 to 15 years. Respondent picture bases this age gets to be seen through table below.

Table 4: Age Profile

\begin{tabular}{|c|c|c|}
\hline Age & Frequency & Percentage \\
\hline 12 & 52 & $30.4 \%$ \\
\hline 13 & 68 & $39.8 \%$ \\
\hline 14 & 45 & $26.9 \%$ \\
\hline 15 & 5 & $2.9 \%$ \\
\hline Total & 171 & $100 \%$ \\
\hline
\end{tabular}

Base table upon acknowledged that observational respondent at most lies on age 13 years by total 68 students (30.4\%), then on age 12 years that total 52 students $(30.4 \%)$, age 14 years that total 45 students $(26.9 \%)$, and last on age 15 years that just total 5 students (2.9\%). The conclusion was the age of student is variety.

\subsection{Moral Disengagement}

Moral disengagement measured by scale of 26 items. This following constitute observational respondent picture bases MD.

Table 5: Moral Disengagement Descriptive Analysis

\begin{tabular}{|l|c|}
\hline Measurement & Score \\
\hline Mean & -0.4046 \\
\hline Median & -0.4100 \\
\hline Modus & -0.45 \\
\hline Deviation Standard & 0.48969 \\
\hline Varian & 0.240 \\
\hline
\end{tabular}

\begin{tabular}{|l|c|}
\hline Range & 2.92 \\
\hline Minimum & -1.80 \\
\hline Maximum & 1.12 \\
\hline
\end{tabular}

Base table upon acknowledged that mean's point as big as 0.4046 , median value 0.4100 , modus point as big as 0.45 , deviation default 0.48969 , variant point 0.240 , range's point 2.92 , minimum point 1.80 , and maximum point 1.12 . Following constitutes histogram and bent is normal curve usufructs variable descriptive analysis moral disengagement.

\subsection{Score of Moral Disengagement}

Table 6: Score of Moral Disengagement

\begin{tabular}{|} 
Table 6: Score of Moral Disengagement \\
\begin{tabular}{|c|c|c|c|}
\hline Explanation & Score & Frequency & Percentage \\
\hline high & $\mathrm{X}>-0.4046$ & 81 & $52.6 \%$ \\
\hline low & $\mathrm{X}<-0.4046$ & 90 & $47.4 \%$ \\
\hline Total & & 171 & $100 \%$ \\
\hline
\end{tabular}
\end{tabular}

Base on the table can be known that exists 81 students (52.6\%) which has disengagement's moral high and 90 students (47.4\%) which have moral disengagement's low. Furthermore the mechanisms of MD such as $35 \%$ Reconstructing Immoral Behavior, $29 \%$ Obscuring Personal Responsibility, 9, 71\% Misrepresenting Injurious Consequences and 26, $11 \%$ Blaming the Victims.

\section{Conclusion}

Children can enroll to the religious schools. Profile shows that many children varieties such as gender, age. Student's at moral disengagement was multiple diverse. For some students, religion is important to control their behavior but for the others is not. Further research need to investigate the process of religious education based on culture.

\section{References}

[1] Rahim H, Rahiem MDH. The use of stories as moral education for young children. Int J Soc Sci Humanit. 2012;2(6):454.

[2] Rossano MJ. The moral faculty: Does religion promote "moral expertise"? Int J Psychol Relig. 2016;18(3):169-94.

[3] Halstead JM. Islamic values: a distinctive framework for moral education? J Moral Educ. 2007;36(3):283-96.

[4] Revell L, Arthur J. Character education in schools and the education of teachers. J Moral Educ. 2007 Mar;36(1):79-92.

[5] Roberts KA, Yamane D. Religion in Sociological Perspective. Sage Publications.; 2011.

[6] Cook CL, Cottrell CA, Webster GD. No good without God: Antiatheist prejudice as a function of threats to morals and values. Psycholog Relig Spiritual. 2015;7(3):217-26.

[7] Sudarsana IK. THE IMPORTANCE OF MORALS TEACHING IN SHAPING THE STUDENTS' CHARACTERS IN SCHOOL. Dharma Acarya Fac Int Semin Proceeding. 2016;1(1):142-9.

[8] Bandura A. Social cognitive theory. W: Annals of child development. Vol. 6. Six theories of child development. Vasta R (red.): JAI Press, Greenwich.;

[9] Bandura A, Barbaranelli C, Caprara G V, Pastorelli C. Mechanisms of moral disengagement in the exercise of moral agency. J Pers Soc Psychol. 1996;71(2):364.

[10] Rosenstock IM, Strecher VJ, Becker MH. Social Learning Theory and the Health Belief Model. Health Educ Q. 1988 Jun;15(2):17583. 